\section{PP2-045 前立腺生検の臨床的検討}

\section{泉大津市立病院泌尿器科}

片岡 喜代徳, 南 高文, 梶川 博司

[目的］前立腺癌の診断に PSA がスクリーニングとして 導入され、早期に癌検出の為に系統的針生検が行われる ようになった。当科に扔ける超音波ガイド下前立腺生検 について臨床的に検討した。[対象と方法] 1999 年 1 月よ り 2003 年 7 月までにPSA 值や直腸診で前立腺癌が疑 われ診断目的のため施行した 196 回の生検を対象とし た。年龄は 28 93 歳 (中央值 71 歳)、PSA は 1.1 5000 $\mathrm{ng} / \mathrm{ml}$ (中央值 $9.9 \mathrm{ng} / \mathrm{ml}$ ) であった。前立腺生検は入院の 上腰椎麻醉を施行し経直腸的超音波ガイド下に会陰から 系統的に6 8 筒所行った。症例により超音波上異常所見 を示す部分も追加施行した。[結果] 73 生検 37\% で癌の 検出を認めた。PSA 值で見た癌の陽性率は $4.0 \mathrm{ng} / \mathrm{ml}$ 以 下: $11 \%(1 / 9) 、 4.1 \sim 10.0 \mathrm{ng} / \mathrm{ml}: 17 \%$ (16/96)、10.1 $20.0 \mathrm{ng} / \mathrm{ml}: 46 \%(21 / 46) 、 20.1 \mathrm{ng} / \mathrm{ml}$ 以上 : $78 \%(35 / 45)$ であった。結語] グレイゾーン症例の癌検出率は低い。 早期に前立腺癌を検出するためには前立腺生検は不可欠 であるが、不要な生検を避けるための検討が必要である。

\section{PP2-046 当院における前立腺生検の検討}

\section{東京医科大学泌尿器科", 東京医科大学病院病院病理 部2)}

坂本 昇"), 古賀 祥嗣"), 秦野 直"), 青柳 貞一郎 ${ }^{1}$,

吉岡 邦彦"), 並木一典"), 大野 芳正 ${ }^{1}$, 黄 英茂 ${ }^{1)}$, 松井 善一", 松本一宏"), 中神 義弘", 芹澤 博美 ${ }^{21}$, 橘 政昭"

【目的】前立腺生検による前立腺癌診断率の向上を图る目的で前立腺 8 ヶ所ないし 10 ケ所生検を行った症例に扔ける辺縁領域最外側部の 癌陽性率を検討し、同部への生検の適応の有用性につき解析した。 【対象と方法】 2000 年 1 月から 2002 年 12 月までに当院にて経直腸的 前立腺針生検を施行された 781 例のうち、通常の 6 ケ所生検に加え て边縁領域最外側部を左右それぞれ 1 所または 2 ケ所ずつ追加採 取(合計 8 ヶ所または 10 ケ所)した 573 例を対象とした。年龄、PSA の中央値は 68.7 歳 (42歳 87 歳)、 $27.9 \mathrm{ng} / \mathrm{ml}(0.4 \mathrm{ng} / \mathrm{ml} \sim 2812 \mathrm{ng} /$ ml）であった。結果】生検で癌が証明された陽性例は 189 例/573 例 $(33.0 \%)$ であった。1 89 例の年齢、PSA の中央值は 69.8 藏（52 歳〜 87歳)、 $62.5 \mathrm{ng} / \mathrm{ml}(2.7 \mathrm{ng} / \mathrm{ml} \sim 2812 \mathrm{ng} / \mathrm{ml})$ であった。边縁領域 最外側の左右どちらか、または左右両方の陽性例は、116 例/189 例 $(61.4 \%)$ であった。特に、19例/189例 $(10.1 \%)$ については、通常 の 6 ケ所生検部位は陰性で、辺縁領域最外僛のみが陽性であった。19 例の内訳は高分化型 5 例、中分化型 6 例、低分化型 8 例で、年齢、PSA の中央値は、68.5歳 (58 歳 $\sim 9$ 歳)、168.1ng/ $\mathrm{ml}$ (3.5ng/ $/ \mathrm{ml} 2812$ $\mathrm{ng} / \mathrm{ml}$ )であった。結語】前立腺生検においては、辺縁領域最外側部 の追加採取が癌診断率の向上に寄与するものと考えられた。

\section{PP2-047 TUR-P 直前の前立腺針生検の試み}

\section{新潟こばり病院泌尿器科 \\ 木村 元彦, 笹川 亨}

【背景と目的】前立腺生検が激增し、一方で切れ味のよい $\alpha$-blocker 薬の普及に伴い、前立腺肥大症の手術は減少 してきた。しかし癌の心配よりも、排尿困難の早期の改 善を第一に希望する患者も多い。癌の見逃しを隇らしつ つ患者満足度を高め医療の効率化をはかることを目標 に、TUR-P 直前の前立腺針生検を行った。対象と方法】 排尿障害の自他覚症状を有する 19 例を対象とした。年齢 は 60-87 歳、PSA は 0.4-17.9ng/mlであった。PSA 值に 関わらず、経直腸エコーガイド下で前立腺針生検を peripheral zone の 6 力所に行い、引き続き TUR-P を施行 した。結果】PSA 4.0 以下の 10 例中 2 例（T1c, T2b）、 gray zone の 6 例中 1 例（T1c）、PSA10.1 以上の 2 例中 1 例 (T3b) の計 4 例が癌であった。Tlc 例は針生検標本 のみで、 T2b 例と T3b 例は針生検・ TUR 標本の双方で 癌が見いだされた【結論】gray zone例では生検のみの 入院を回避できた。触診正常で PSA 4.0 以下の例で前立 腺癌を発見できた。生検単独に比べ排尿症状の改善も得 られた点、TUR 単独と比べ入院期間を変えることなく癌 の発見率を高めた点から、本法は有用と考えられた。

\section{PP2-048 Gray zone PSA 例の前立腺生榙にお ける CRP 值の有用性}

\section{東京医科大学八王子医療センター"1, 東京医科大学霞ヶ 浦病院 ${ }^{2}$, 社会保険蒲田総合病院 ${ }^{3)}$, 西東京中央総合病 院 ${ }^{4}$}

野田 賢治郎 ${ }^{11}$, 細田 悟1), 大鶴 礼彦", 松本太郎”, 山本 豊"), 吉川 慎一 ${ }^{11}$, 松本 哲夫 ${ }^{11}$, 伊藤 貴章 ${ }^{2)}$,

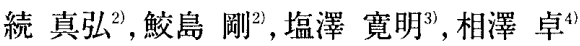

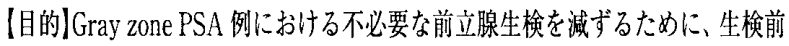
CRP 值が有用な゚ラメーターとなりうるか否かを検討した。

【㸚象と方法】2002年 10 月加 2003 年 8 月の間に生㛟老施行した 308 例のう ち、PSA が gray zone で生検前にCRP 值力測定してあり明らか子炎炎症性疾患

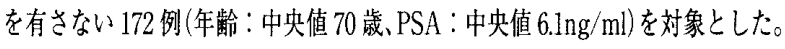

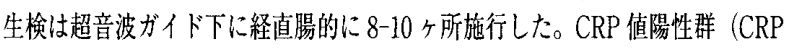
ミ0.3）は 30 例 $(17 \%$ )、除性群は 142 例 $(83 \%)$ あり、両群間で検討した。

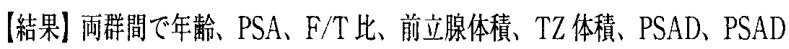
一TZ纪差は無加った。前立腺癌が 21 例 (12\%) 亿検出され、全侧が CRP 值除 性群であった。CRP 值㓌性群に限って生检を施行すると、17\% (30/172) の生 検を減することが可能で、感度を下げることなく癌検出率は 15\% (21/142) に 若干向上した。また category IV prostatitis (NH， 1995) が CRP 值晹性群で は $77 \%$ 、除性皏では $48 \%$ で、CRP 值陽性群に多い㥧向があった。

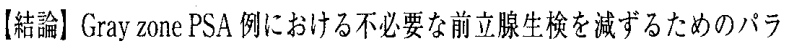
メーターとして、CRP 值泣有用である。明らかな炎症性疾患を有さないGray zone PSA 例では、 category IV prostatitisが一因となり PSA およびCRPが上 昇している可能性が示唆された。 